Literature in pieces: female sanctity and the relics of early women's writing (500-1150)

\title{
Diane Watt
}

Credimus autem multo plura quam reperiantur extitisse, que aut ex illius eui torpentium scriptorum negligentia nequaquam litteris mandata fuerunt, aut descripta paganorum rabie ecclesias ac cenobia depopulante inter cetera perierunt.

[And we believe that there are many more (miracles) than are now to be found, which through the carelessness of the sluggish scribes of that age were never committed to writing, or were recorded but have perished among other things when the fury of the heathen laid waste to churches and monasteries. ${ }^{1}$

It is the sound of memory at work, creating a necklace of narrative. ${ }^{2}$

\section{Women’s literary historiography}

Literary histories of English women's writing have, traditionally, had little time for the early medieval period. Early medieval women are excluded from teleologies that celebrate the emergence of authorship and literature, understood in specific and restrictive terms, and that

\footnotetext{
${ }^{1}$ Miracvla Sancte Etheldrethe in Goscelin of Saint-Bertin, The hagiography of the female saints of Ely, ed. and trans. Rosalind C. Love (Oxford: Clarendon Press, 2004, pp.98-99.

2 Jane Urquhart, The underpainter (London: Bloomsbury, 1998) p.9.
} 
only acknowledge certain narrowly defined forms of textual production. They are omitted from linear temporal paradigms that already struggle to accommodate the vernacular visionary writings of the later medieval period and the devout poetry of the Renaissance, but which incorporate far more easily the dramatic texts of the seventeenth century and the prose writings of the eighteenth and nineteenth. One example of such an exclusive literary history is The Norton anthology of literature by women: the traditions in English, edited by Sandra M. Gilbert and Susan Gubar, now in its third edition (2007). While more self-consciously aware than the previous editions of its theoretical and methodological limitations, the revised introduction nevertheless follows the earlier versions in asserting that 'we find no texts in the Old English period that have been definitively identified as composed by women'. ${ }^{3}$ With this claim, and without any further consideration of what is a 'text' or what assumptions underlie the phrase 'composed by women', the entire literary history of women prior to c.1170 (the date when Marie de France, the earliest author included in the revised Norton anthology, flourished) is summarily dismissed.

This pattern is, somewhat surprisingly, repeated in more period-specific women’s literary histories. ${ }^{4}$ The Cambridge companion to medieval women's writing, edited by Carolyn Dinshaw and David Wallace (2003) includes the early Middle Ages in its chronological table and makes reference to a number of European women in the centuries leading up to 1150

\footnotetext{
${ }^{3}$ The Norton anthology of literature by women: the traditions in English, third edition, 2 vols. (New York: W.W. Norton, 2007), vol. 1, p.1.

${ }^{4}$ Clare A. Lees and Gillian R. Overing make a similar point: Double agents: women and clerical culture in Anglo-Saxon England, new edition (Cardiff: University of Wales Press, 2009), p.6.
} 
(such as Radegund, Dhuoda, Hrotswith of Gandersheim, Hildegard of Bingen, Heloise) and also some key English women from the same period (such as Hild of Streonæshalch or Whitby, Æthelburh and Hildelith of Barking, Leoba and Boniface’s other women correspondents, Eve of Angers, Christina of Markyate). ${ }^{5}$ However, once again, with minor exceptions (a fleeting reference to the anonymous Old English poems 'The Wife's Lament' and 'Wulf and Eadwacer') the early medieval period is simply overlooked. ${ }^{6}$ Indeed histories of medieval women's writing that do include the early medieval period, such as Laurie A. Finke's Women's writing in English: medieval England (1999), or The History of British women's writing, 700-1500, edited by Liz Herbert McAvoy and Diane Watt (2012), are the exception rather than the rule. ${ }^{7}$ This exclusion of the period before 1150 from women’s literary history is, of course, all the more problematic because even later medieval women writers continue to fit uncomfortably within the dominant masculinist paradigms of traditional literary history, as is so vividly illustrated by the scant attention paid to women in

\footnotetext{
${ }^{5}$ The Cambridge companion to medieval women's writing (Cambridge: Cambridge University Press, 2003), pp.viii-xii.

${ }^{6}$ Jennifer Summit, 'Women and authorship' in The Cambridge companion to medieval women's writing, ed. Dinshaw and Wallace, p.95.

${ }^{7}$ Laurie A. Finke, Women's writing in English: medieval England (London: Longman, 1999); The History of British women's writing, 700-1500, vol. 1, ed. Diane Watt and Liz Herbert McAvoy and Diane Watt (London: Palgrave, 2012). See especially Clare A.Lees and Gillian R. Overing 'Women and the origins of English Literature' in History of British women's writing, 700-1500, ed. McAvoy and Watt, pp.000-000.
} 
The Cambridge history of medieval English literature, edited by David Wallace (1999) or, more recently, Christopher Cannon's The grounds of English literature (2004). ${ }^{8}$

Studies which have addressed women’s different relationship to authorship and literary production in the later Middle Ages have examined such questions as women’s exclusion from medieval definitions of authority (associated with the classical writers and Church patriarchs) and the problems of attribution posed by anonymous texts; women's more limited access to formal education, especially outside the convents and courts; their reliance on readers, secretaries, and scribes; and their more 'indirect' engagement with writing (from a modern perspective at least) as visionaries, translators and compilers. ${ }^{9}$ These issues are also relevant to the early medieval period, where the problem of the dearth of a category of 'women’s writing' is felt all the more acutely. Gilbert and Gubar are of course wrong to suggest that there are 'no texts in the Old English period that have been definitively identified as composed by women’. By including the phrase ‘definitely identified’, Gilbert and Gubar

\footnotetext{
${ }^{8}$ See my review of The Cambridge history: Diane Watt, 'The Manly Middle Ages', English 49 (2000), 177-81 . In his discussion of the Bayeux Tapestry, for example, Cannon does not consider the possible roles of women in its patronage or production: Christopher Cannon, The grounds of English literature (Oxford: Oxford University Press, 2004), pp.24-29; contrast Elisabeth van Houts, Memory and gender in medieval Europe 900-1200 (Houndmills, Basingstoke: Macmillan, 1999), pp.101-2.

${ }^{9}$ Finke, Women's writing in English; Summit, 'Women and authorship’; Diane Watt, Medieval women's writing: works by and for women in England, 1100-1500 (Cambridge: Polity, 2007), pp.1-18.
} 
neatly sidestep the controversial issue of anonymous texts for which a case for attribution to women might be made. Yet, aside from this omission, there still survives a body of texts by women, albeit composed in Latin, from before 1150, including prayers, hymns, and verses. ${ }^{10}$ Some of the surviving texts were composed by English women overseas. Hygeburg or Hugeburc ( $f l .760-786$ ), an Anglo-Saxon nun who joined the Benedictine monastery of Heidenheim in Germany wrote lives of the brothers St Willibald and St Wynnebald; the former includes an early pilgrim travel narrative. ${ }^{11}$ Hygeburg may lay claim to the title of first English woman writer of a full length literary work whose name is known, but the letters of Leoba, formerly Leofgyth, (c.700-780), an Anglo-Saxon missionary in Germany, and of the other female correspondents of Boniface and his circle, provide more examples of early women’s engagement with literary cultures. Leoba’s first letter to Boniface notably includes four lines of Latin verse, and she states that she learnt the art of poetry from her teacher Eadburg. ${ }^{12}$ There is evidence that more Latin writing must have existed within England,

${ }^{10}$ Peter Dronke, Women writers of the Middle Ages: a critical study of texts from Perpetua (†203) to Marguerite Porete (†1310) (Cambridge: Cambridge University Press, 1984), pp. 30-35; Jane Stevenson, 'Anglo-Latin women poets' in Latin learning and English lore: studies in Anglo-Saxon literature for Michael Lapidge, ed. Katherine O’Brien O’Keeffe and Andy Orchard, 2 vols. (Toronto: University of Toronto Press, 2005), vol.ii, pp.86-107; Jane Stevenson, Women Latin poets: language, gender, and authority from Antiquity to the eighteenth century (Oxford: Oxford University Press, 2005).

${ }^{11}$ See Pauline Head, 'Who is the nun from Heidenheim? A study of Hugeburc's Vita Willibaldi', Medium Avum 71 (2002), 29-46.

${ }^{12}$ Boniface, Die Briefe des heiligen Bonifatius und Lullus, ed. Michael Tangl, reprinted edition (Munich: Monumenta Germaniae Historica, 1989), vol.i, pp.52-53; Boniface, The 
including the early twelfth century work, now lost, of Muriel of Wilton, described as 'inclyta versificatrix’ [famous poetess]. ${ }^{13}$

Evidently and unsurprisingly, the earliest medieval women’s writing was produced by abbesses and nuns - the double monasteries of nuns and monks were centres of scholarship and literary culture — and thus certain types of literature were favoured by women. As we will see, Abbess Hildelith of Barking (fl.700), wrote visionary accounts herself, which did not survive. Hagiographies were also popular: an early but lost life of Hild (614-680), may have been authored by nuns in their subject's own monastery. Foundation narratives derived from versions originally attributable to women that have come down to us include an Old English fragment of a life of St Mildrith: the legend itself dates to the time of Mildrith's successor, Eadburg of Minster-in-Thanet (c.732-751)— who translated Mildrith’s remains and fostered her cult. ${ }^{14}$ These texts were concerned with establishing the saintly reputations of the early abbesses, and securing the future of the religious houses. In the later period, following the

English correspondence of Saint Boniface: being for the most part letters exchanged between the apostle of the Germans and his English friends, trans. Edward Kylie (London: Chatto and Windus, 1911), pp.110-111; see also Christine E. Fell, 'Some implications of the Boniface correspondence' in New readings on women in Old English literature, ed. Helen Damico and Alexandra Hennessey Olsen (Bloomington: Indiana University Press, 1990), pp.29-43.

${ }^{13}$ Stevenson, ‘Anglo-Latin women poets,' p.95; J.S.P. Tatlock, 'Muriel: the earliest English poetess', PMLA 48 (1933), 317-21.

${ }^{14}$ Stephanie Hollis, ‘The Minster-in-Thanet foundation story’, Anglo-Saxon England 27 (1998), 41-64. 
Benedictine reform, it was royal women in particular who played a key role in cult making. Queens Emma (c.988-1052) and Edith (c.1029-1075) commissioned family histories which focused on the lives of their male relatives, but in which they themselves figured. ${ }^{15} \mathrm{By}$ embracing a more fluid or elastic definition of textual production as collaborative, a definition that allows us to take into account processes such as patronage, and by paying attention to audience as well as authorship it is possible to grasp more fully the nature and extent of women's engagement with and contribution to literary culture in the early medieval period. Furthermore, by challenging the preconception that the Old English period simply ended with the Norman invasion, and by acknowledging continuities into the centuries that followed, it is possible to trace a longstanding tradition of the transmission and rewriting of texts about saintly women that spans the entire Middle Ages. ${ }^{16}$

${ }^{15}$ Encomium Emmae reginae, ed. Alistair Campbell, reprinted edition with a supplementary introduction by Simon Keynes, Cambridge classic reprints (Cambridge: Cambridge University Press, 1998); The life of King Edward who rests at Westminster attributed to a monk of Saint-Bertin, ed. and trans. Frank Barlow, second edition (Oxford: Clarendon Press, 1992); see Pauline Stafford, Queen Emma and Queen Edith: queenship and women's power in eleventh-century England (Oxford: Blackwell, 1997), esp. pp.28-52; and Elizabeth M. Tyler, 'Fictions of family: the Encomium Emmae Reginae and Virgil’s Aeneid', Viator 36 (2005), 149-79.

${ }^{16}$ [continuity will be addressed by a number of chapters-add cross ref later]. On the continuity of traditions of female sanctity, see, for example, Virginia Blanton, Signs of devotion: the cult of St. Athelthryth in medieval England, 695-1615 (University Park, Pennsylvania: the Pennsylvania State University Press, 2007); and Jocelyn Wogan-Browne, 
The question of ‘literary historiography' is crucial to understanding early medieval women’s engagement with literary culture. One point to emphasise is that many of the arguments put forward to explain and, indeed, to counter the apparent dearth of women writers in the late Middle Ages, do not fully account for the greater intensity of the problem in the early medieval period. Allen J. Frantzen points out that most early medieval writing exists in only partial form and that fragments are indeed 'a staple of Anglo-Saxon culture' ${ }^{17}$

Unsurprisingly, then, there remain only pieces or traces of early medieval women’s writing. Furthermore, while scholars may continue to debate whether the early Anglo-Saxon period represented a golden age for women's scholarship and learning compared to subsequent centuries, it would simply be wrong to attempt to explain the early dearth of women's writing with a progress narrative that claims that the emergence and development of women's writing runs parallel to greater access across time to literacy and learning. ${ }^{18}$ Feminist historians have long argued that women's history does not simply mirror that of men, and that the great Saints' lives and women's literary culture c.1150-1300: virginity and its authorizations, (Oxford: Oxford University Press, 2001), esp. pp.57-66.

${ }^{17}$ Allen J. Frantzen, 'The fragmentation of cultural studies and the fragments of Anglo-Saxon England', Anglia 114 (1996), 310-29; at 320. Frantzen’s theorization of fragmentary texts as 'fragments of cultural processes now cut off from the social worlds in which they once functioned' (321) has considerable relevance to my own argument about the surviving traces of early women's writing.

${ }^{18}$ Stephanie Hollis, Anglo-Saxon women and the Church: sharing a common fate, (Woodbridge: Boydell Press, 1992), pp.1-14. 
ruptures and transitions of traditional chronological accounts do not, necessarily, equally apply to women. One powerful recent response has been to emphasise continuity in women's history instead of change. ${ }^{19}$ For students of the history of women in early medieval England, somewhat different considerations arise because, arguably, some ruptures and transitions did have a greater and more destructive impact on women. I noted above that Dinshaw and Wallace’s Cambridge companion does include the period before 1150 in its chronological table, and some key women are mentioned therein. Nevertheless, the emphasis is very much on beginnings: ‘c.424 Anglo-Saxon incursions into England begin’; ‘665-75 Barking Abbey founded’; '889 Marriage of Alfred’s daughter Aethelflaed’; 'Late 1060s-mid 1090s The Bayeux Tapestry depicting the events of the Norman Conquest is designed and executed' ${ }^{20}$ Yet endings are important for women's history too, and, perhaps especially in relation of early medieval women's history, it is vital that equal attention is paid to them in order for discontinuities to be properly understood. A very different perspective is seen, if for example, the destruction of the convents and the slaughter of the nuns by the Vikings is highlighted, and the consequential loss of books and other cultural artefacts, or if the negative impact of the tenth-century Benedictine Reform on aristocratic religious women's power and privilege is traced. One significant change in the later Anglo-Saxon period was the replacement of double monasteries with segregated female communities, and the loss of educational and literary opportunities that entailed. At the same time, some historians of women have suggested, compellingly, that the impact of the Norman invasion on women can

${ }^{19}$ Judith M. Bennett, History matters: patriarchy and the challenge of feminism (Manchester: Manchester University Press, 2006), pp.60-81.

${ }^{20}$ Cambridge companion, pp.viii-x. 
be easily overstated. ${ }^{21}$ One of the most developed critiques of traditional approaches to history is found in Judith Bennett's History matters, in which she argues that feminist historians need to be 'less safe and more offensive'.22 A key study of women in Anglo-Saxon textual culture that is willing to take risks is Clare A. Lees and Gillian R. Overing's Double agents (first published 2001). ${ }^{23}$ In this work, Lees and Overing suggest that behind the absence of women lies the structural misogyny of Anglo-Saxon clerical culture. In their brilliant first chapter, Lees and Overing argue that both the Anglo-Saxon religious historian Bede and twentieth-century Anglo-Saxonists have conspired in their representation to Cædmon’s Hymn as the ‘birth’ of English poetry to overlook the role of Cædmon’s patron, Abbess Hild, in this originary narrative. Indeed, as we will see, a clerical writer such as Bede was not only capable of forgetting women in their roles as patrons or authors, but he also dismissed them as authoritative witnesses, and freely appropriated their work, without acknowledgement, into his own. ${ }^{24}$ The extent of this systematic overwriting of the women's writing of the early medieval period should not be underestimated.

${ }^{21}$ Stephanie Hollis, with W.R. Barnes, Rebecca Hayward, Kathleen Loncar and Michael Wright (eds.), Writing the Wilton women: Goscelin's legend of Edith and Liber confortatorius, Medieval Women: Texts and Context vol. 9 (Turnhout: Brepols, 2004), p.8; Anne L. Klink, ‘Anglo-Saxon women and the law’, Journal of Medieval History 8 (1982), $107-21$.

${ }^{22}$ History matters, p.154.

${ }^{23}$ Lees and Overing quote Bennett in the revised preface to the 2009 reissue of Double agents, p.xiii.

${ }^{24}$ See also Rudolf of Fulda, whose life of Leoba is, according to Lisa Weston, ‘appropriated...from the memory and oral tradition of her nuns': Lisa M. C. Weston, 
Elsewhere, I have argued that it is possible to create a 'tradition' of women writers that included medieval women, 'albeit not along continuous vertical masculinist lines of influence and anxiety of influence, but along broken and sometimes horizontal lines of congruence and commonality in relation to production and reception'. ${ }^{25}$ It is worth pausing to consider not only why vertical lines of literary influence do not work for early women's writing (the dearth of texts makes this self-evident), but just how restrictive such conceptualizations are. Vertical models of literary history are often expressed in terms of genealogy: writers have their literary forefathers and descendents. Such genealogical framing privileges the masculine, of course, but is also élitist in its underpinning (only the aristocracy and the wealthy can reconstruct their genealogies). The feminist response to replace patrilineage with matrilineage addresses part of the problem, and also mirrors the spiritual teleologies of the reconstructed, and at times spurious, histories of the early convents, as transmitted by the later writers of the lives of saints of Ely which draw out the familial connections between the sisters Æthelthryth (c.636-679) and Seaxburh (c.655-c.700), and follows a maternal line from Seaxburh through her daughter Eormenhild (d.c.700), and her child Wærburh (d.700), and so on. ${ }^{26}$ The idea of creating female genealogies may even have its origins in female-authored Anglo-Saxon

'Sanctimoniales cum sanctimoniale: particular friendships and female community in AngloSaxon England' in Sex and sexuality in Anglo-Saxon England: essays in memory of Daniel Gillmore Calder, ed. Carol Braun Pasternack and Lisa M.C. Weston (Tempe, Arizon: Arizona Center for Medieval and Renaissance Studies, 2004), p.51. Weston also discusses Bede's HE 4 in this essay.

\footnotetext{
${ }^{25}$ Watt, Medieval women's writing, p.159.

${ }^{26}$ Goscelin of Saint-Bertin, Hagiography of the female saints of Ely, ed. and trans. Love.
} 
lives. $^{27}$ Jocelyn Wogan-Browne--discussing a thirteenth-century life of the founding abbess of Ely, written by a nun called Marie, possibly of Chatteris--has argued that such models are potentially subversive: 'the virgin foundress simultaneously disrupts biological lines of filiation and creates spiritual genealogies' ${ }^{28}$ Other scholars are more critical. Susan Ridyard draws attention to the ways that the different generations of women seem to compete in levels of sanctity. ${ }^{29}$ Lees and Overing point out that the dual emphasis on virginity and what they term ‘spiritual maternity’ both 'conceals and devalues real connections between women' and 'minimizes the value and reality of physical maternity'. ${ }^{30}$ A further point that should be made in a discussion of genealogical metaphors is that familial lines do die out. Again, this seems particularly pertinent in the case of women's history: even the saintly history of Barking (the Anglo-Saxon female foundation to have enjoyed the most continuous history having been re-established in the tenth-century as a Benedictine convent) came to an end with the Reformation. However, more radical attacks on ideas of genealogy come not from feminism, but from queer theory. Foucauldian models of genealogy have been crucial to queer histories, yet queer historians and literary critics have recently launched a full-scale attack on traditional periodization, linear chronologies and heterosexual reproductive teleologies, arguing for a more radical 'unhistoricism' and demanding ‘acts of queering that would suspend the assurance that the only modes of knowing the past are either those that regard the past as wholly other or those that can assimilate it to a present assumed identical to

\footnotetext{
${ }^{27}$ See Hollis, 'Minster-in-Thanet', 46 and 56-8.

${ }^{28}$ Wogan-Browne, Saint's Lives, p.210.

${ }^{29}$ Susan J.,Ridyard, The royal saints of Anglo-Saxon England: a study of West Saxon and East Anglian cults (Cambridge: Cambridge University Press, 1988), p.91.

${ }^{30}$ Lees and Overing, Double agents, p.43.
} 
itself'. ${ }^{31}$ While we might not want to accept wholesale a de-chronological approach that would simply reify our sense that early medieval women's writing is out of time, the idea that the texts considered here might be seen to touch other later texts, across time, and without firm evidence of direct influence, can be enabling. ${ }^{32}$ Rather than seeking to establish direct continuities where they do not appear to exist, we should embrace the disrupted, discontinuous, fragmentary nature of the history that has come down to us. The history of early medieval women's writing is that of a literature reduced to pieces; a corpus of work broken up like the corpse of a saint that has been subjected to relic hunters, thieves and heathen invaders. While an approach that acknowledges loss and emphasises fragmentation cannot counter fully the élitist character of the surviving evidence of early medieval women's literary culture, it can make it possible to explore connections that have not previously been visible. In the next section, I will examine some of the evidence that early women's writing was deliberately appropriated and overwritten by clerical authors. In the final section of this essay, I will examine some of the ways in which the early medieval women saints considered here touch one later woman to whom they are not overtly related: Christina of Markyate (c.1096-after 1155).

The overwriting of female sanctity

\footnotetext{
${ }^{31}$ Jonathan Goldberg and Madhavi Menon, 'Queering history’, PMLA 120 (2005), 1608-17 at 1616; Carolyn Dinshaw and Karma Lochrie, letter to the editor, PMLA 121 (2006), 837-8; Menon, reply, PMLA 121 (2006), 838-9.

${ }^{32}$ See Carolyn Dinshaw, Getting medieval: sexualities and communities, pre- and postmodern (Durham, NC: Duke University Press, 1999).
} 
As I have suggested, the main evidence of early women's engagement with literary culture in England derives from two related genres: saints’ lives and visionary writing. In terms of subject matter, its primary but not only focus was on female sanctity. My central argument here is that early women's texts were overwritten by monastic historians, hagiographers, and writers of works of instruction and/or encouragement for women. It is worth pausing on my choice of language here: why 'overwrite’? According to the Oxford English Dictionary, the verb 'overwrite' can simply mean 'to rewrite'. ${ }^{33}$ The examples cited by the OED relate to Shakespeare's adaptations of his sources, and to the discussions of the Old Testament. However, 'overwrite’ can also mean ‘to write (something) over other writing' ${ }^{34}$ I argue here that, metaphorically, this is what the monastic writers do: they write their texts over the women’s own accounts, whether written or oral. In this sense they create a palimpsest: 'a manuscript in which later writing has been superimposed on earlier (effaced) writing' or 'a thing likened to such a writing surface, esp. in having been reused or altered while still retaining traces of its earlier form; a multilayered record’. ${ }^{35}$ In what follows, I am concerned with identifying the traces of the earliest women's writing in the surviving record. However I am also concerned with thinking about the processes or acts of effacement that took place. The sense that such acts were deliberate is captured in the meaning of 'overwriting' as it is used in a computing context: 'to destroy (data) by entering new data in its place; to place new data in (a memory location, a file, etc.) and destroy the existing contents’ ${ }^{36}$ Such data, if

\footnotetext{
33 OED s.v. 'overwrite’, 4.

${ }^{34}$ OED s.v. 'overwrite', 2a.

${ }^{35}$ OED s.v. 'palimpsest', 2a and 2b.

${ }^{36}$ OED s.v. 'overwrite', 2c.
} 
overwritten completely, is unrecoverable; although copies may still exist, at least for some time, as for example would be the case with web pages that have been cached by major search engines. For the male writers discussed here, overwriting was, presumably, not viewed as destructive, but a means of improving on their sources; and copies of those sources, the 'underwriting' may well have remained in circulation for some time after the overwritten texts were produced. The very fact that multiple versions of saints' lives survive suggests that the process of overwriting was an inherent aspect of a genre which required the continual revision, updating and translation of earlier sources.

Overwriting might be compared to overpainting. The OED defines the verb 'overpaint' as 'to paint over; to cover with another colour or layer of paint; to form such a layer over (something). ${ }^{37}$ This definition is inadequate as it does not recognize the distinction between 'overpainting' as technique practiced by the original artist whereby the overpainting and the underpainting work together to create a distinct effect; 'overpainting' as a process of restoring a damaged work; and 'overpainting' as a means by which artists might adapt an earlier work of art that is deemed old fashioned or inappropriate in some way to reflect contemporary standards and tastes. This sort of 'overpainting' is sometimes linked to censorship. It is this last meaning that might be most useful in helping us understand what the monastic writers discussed here attempted to achieve. Such writers try to ensure the preservation and transmission of aspects of the underwriting, even as they adapt it. Dana Oswald's study of different kinds of erasure within the illustrations and written descriptions of monsters in the manuscripts of the Anglo-Saxon Wonders of the East captures the

\footnotetext{
${ }^{37}$ OED s.v. 'overpaint', 1.
} 
complexity of these processes. ${ }^{38}$ Oswald identifies three types of erasure: never drawing; removal; and revision. The third type, revision, is closest to 'overpainting' and 'overwriting' and Oswald's words of caution are apposite: 'It is easy to miss the traces of what was there before because they are buried under and perhaps even incorporated into the newly constructed and censored meaning' ${ }^{39}$ My use of the word 'overwrite' attempts to keep the multiple connotations of 'destruction', 'preservation', 'control' and 'suppression' simultaneously in play.

Bede

The first example of the overwriting of female sanctity comes from the beginning of our period: Bede’s Historia Ecclesiastica. Book four of HE, a work as a whole concerned with chronicling the foundation of the English church, includes the lives of three founding abbesses: Hild of Whitby; Æthelburh (Ethelburga) of Barking (fl.664); and Æthelthryth (Etheldreda) of Ely. The lives of all three women, who wielded considerable political as well as religious power, suggest that Anglo-Saxon female sanctity fitted into a longstanding tradition of women's visions and prophecy that originated in the pre-Christian era and continued to the Reformation and beyond. ${ }^{40}$ Bede's accounts of these élite women elide their

${ }^{38}$ Dana Oswald, Monsters, gender, and sexuality in medieval English literature (Cambridge: D.S. Brewer, 2010), pp.27-65.

${ }^{39}$ Oswald, Monsters, gender, and sexuality, pp.53-4.

${ }^{40}$ See Diane Watt, Secretaries of God: women prophets in late medieval and early modern England (Cambridge: D.S. Brewer, 1997). 
sources, which were almost certainly lives of the foundresses originally composed within their own religious houses. It is certainly reasonable to assume that in $H E 4.23$, Bede must have drawn on a lost life of Hild from the double monastery at Whitby. ${ }^{41}$ Certainly, Whitby was a site of literary production, and it may be that the sisters themselves played a central role: Stephanie Hollis hypothesizes that the Whitby Life of Gregory could have been written by a nun. ${ }^{42}$ In failing to acknowledge his sources then, Bede adapts Hild's life to fit his own agenda, part of which seems to be to remove surviving traces of Hild's own scholarly textual community. ${ }^{43}$ This is vividly illustrated by the writing out of Hild's role as patron of the poet Cædmon in HE 4.24, analysed by Lees and Overing, that was mentioned above. However, this is not the limit of Bede's agenda, as he also very deliberately excludes from HE 4.23 any mention of the Synod of Whitby, over which Hild herself presided (discussion of her role is limited to a couple of sentences in $H E$ 3.25, pp.298-9, where he mentions briefly that she took the Celtic side, whereas Bede himself took the Roman side) ${ }^{44}$ In his account of Hild's life, Bede emphasises her personal devotion and her close association with Bishop Aidan and her role as spiritual mother of bishops, but without making it explicit that Hild was personally responsible for educating these men. The religious and political were profoundly imbricated

${ }^{41}$ J.E. Cross, 'A lost life of Hilda of Whitby: the evidence of the Old English martyrology', The early Middle Ages, Acta 6 (1979), 21-43.

${ }^{42}$ Hollis, Anglo-Saxon women and the church, pp.125-27.

${ }^{43}$ See Peter Hunter Blair, 'Whitby as a centre of learning in the seventh century' in Learning and literature in Anglo-Saxon England: studies presented to Peter Clemoes on the occasion of his sixty-fifth birthday, ed. Michael Lapidge and Helmut Gneuss, Cambridge: Cambridge University Press, 1985, pp.3-32; Hollis, Anglo-Saxon women and the church, pp.243-70.

${ }^{44}$ Lees and Overing, Double agents, p.31. 
in one another, as Hild's career illustrates. Yet Bede initiates a tendency to emphasis the religious over the political when discussing female saints and visionaries that continues right up to present day historicism. Bede is also very selective in what he reveals about Hild's personal life. Aside from recording her royal family connections and her conversion, he reveals little more about the first half of her life, choosing instead to dwell on the events that followed her profession. His reason for this is may have been, as Hollis hypothesises, that Hild was that a widow, rather than a virgin, when she became a nun and that she did not comfortably conform to his own expectations of female sanctity. ${ }^{45}$

In his account of her life, Bede effectively depoliticizes and decontextualizes Hild's sanctity, remoulding it to fit his own model. He even omits from his life her two powerful relatives and allies, who succeeded her as abbesses of Whitby, Ælfflæd (654-714) and her mother Eanflæd (626-after 685), despite discussing them elsewhere. ${ }^{46}$ Yet one of these women probably commissioned the writing of Hild's lost life. What traces, if any, then remain of the underwriting, the life, or lives that Bede drew on; the text, or texts, that more closely reflected the interests and concerns of Whitby itself, and that may have been authored by Hild's fellow nuns? It seems reasonable to assume that Bede's narrative of the dream of a necklace experienced by Hild's mother Breguswith comes, if in mediated form, from his source (HE 4.23 pp.410-11). Breguswith understood the necklace to represent her daughter, who would become a shining example to others. This prophetic vision was mirrored by others at the end of Hild's life: visions of the ascension of Hild's soul witnessed by nuns at Whitby and its neighbouring house at Hackness (HE 4.23, pp.413-14). These visions serve to authorize the

\footnotetext{
${ }^{45}$ Hollis, Anglo-Saxon women and the church, p.248.

${ }^{46}$ Lees and Overing, Double agents, pp.31-2 and 68-71.
} 
holiness of the saint and her community in positive terms which the nuns themselves would have recognized and considered worthy of commemoration. ${ }^{47}$ Here Bede has no choice but to acknowledge the authority of the visionaries themselves--Breguswith, Begu (the nun at Hackness), and an anonymous Whitby novice. Indeed Bede even names another female witness to validate Begu’s dream: Frigyth, who presided over Hackness.

Visions of the dying, experienced by the dying, or concerning the dead, also figure in Bede's account of the early history of Barking Abbey, founded by Eorcenwold for his sister Æthelburh (HE 4.6-10). According to Bede, Abbess Æthelburh’s death and is predicted by a vision of the ascension of her soul (HE 4.9), witnessed by Torhtgyth, a close ally of Æthelburh within the convent, but this is only one of a series of such visions experienced in monastery. ${ }^{48}$ Most notably, Torhtgyth has a vision of the dead abbess calling her to heaven as she herself lies dying, but there are others, including visions relating to the positioning of the nuns' cemetery. Bede's HE includes a number of prophecies of death, and visions of the otherworld and of the dying and the dead, which reflects how widespread such revelations and other tomb miracles were in the seventh century. Many of these are concerned with male visionaries, rulers, saints and sinners, such as Oswald, Fursa, Chad, Cuthbert, and Dryhthelm. However there is compelling evidence that such visions were of particular significance within a female context and circulated amongst female communities. Around 715 or 716 Boniface wrote to Eadburg as follows:

\footnotetext{
${ }^{47}$ Diane Watt, 'Authorizing female piety’ in The Oxford handbook of medieval literature in English, ed. Elaine Treharne and Greg Walker with the assistance of William Green (Oxford: Oxford University Press, 2010), pp.242-46.

${ }^{48}$ See Weston, 'Particular Friendships’, pp.35-43.
} 
Rogabas me, soror carissima, ut admirandas visiones de illo redivivo, qui nuper in monasterio Milburge abbatisse, mortuus est et revixit, quae ei ostense sunt, scribendo intimare et transmittere curarem, quamadmodum istas veneranda abbatissa Hildelida referenti didici.

[Thou didst ask me, dear sister, to send you an account as the venerable Abbess Hildelida [Hildelith] gave it to me [Boniface] of the wonderful vision seen by the man who recently, in the convent of Abbess Milburga [Milburg, abbess of Much Wenlock], died and came back to life]. ${ }^{49}$

Hildelith was, of course, Æthelburh’s successor at Barking. Although Boniface rejects Hildelith's account of the vision of the monk of Much Wenlock in favour of the testimony of the visionary himself, this fleeting reference indicates that Hildelith had written down a now lost text of the vision, which she then passed on to others. Furthermore it confirms that Hildelith was part of Boniface's textual community. In this context if is worth remembering that Barking under Hildelith was a centre of literary culture and learning, and that Aldhelm's De virginitate, which was written for Hildelith and her nuns, praises their skill and eloquence in letter writing. Aldhelm also indicates that they wrote verse, and were interested in histories

\footnotetext{
${ }^{49}$ Boniface, Die Briefe, ed. Tangl, p.8; Boniface, English correspondence, trans. Kylie, p.78; see Patrick Sims-Williams, Religion and literature in western England 600-800, Cambridge Studies in Anglo-Saxon England 3 (Cambridge: Cambridge University Press, 1990), pp.243272.
} 
and chronicles as well as Scripture and Biblical commentaries. ${ }^{50}$ Stylistically Aldhelm’s text, with its overwraught and thus, in another sense of the word, overwritten Latin, provides compelling evidence of the high levels of literacy and learning of Barking. This assessment is supported by Bede, who indicates that the key source for his accounts in the Historia Ecclesiastica of the visions of Barking, including those of Torhtgyth, was a liber [book] or libellus [pamphlet] (HE 4.10, pp.364-5) that had been compiled there and widely distributed:

In hoc etenim monasterio plura uirtutum sunt signa patrata, quae et ad memoriam aedificationemque sequentium ab his qui nouere descripta habentur a multis; e quibus et nos aliqua historiae nostrae ecclesiasticae inserere curauimus.

[In this monastery many signs and miracles were performed which have been written down by those who were acquainted with them as an edifying memorial for succeeding generations and copies are in the possession of many people. Some of these we have taken care to insert in this History.] (HE 4.7, pp.356-7)

It is likely that Torhtgyth's visions, which are explicitly recognized here as a form of memorialisation, were indeed originally recorded by the nuns themselves. It is striking that, according to this account, they seem to have been widely circulated. Thus they represent at least aspects of the underwriting that lies behind Bede’s version. Hildelith, as Æthelburh’s successor and concerned to ensure the continuity of Barking by fostering the cult of its

\footnotetext{
${ }^{50}$ Aldhelm, De virginitate in The prose works, trans. Michael Lapidge and Michael Herren (Cambridge: D.S. Brewer, 1979), pp.59 and 61-2. The poetic version of De virginitate was also written at the request of the nuns.
} 
foundress, would have commissioned the writing of this liber, and she may even have written it herself. Yet Bede makes no mention of this is his discussion of Hildelith in HE 4.10.

Within the HE, Bede's ideal of female sanctity is however neither Hild, nor Æthelburh, but Æthelthryth of Ely, whose life and death he describes in HE 4.19-20, and about whom he composes his Hymn (HE 4.20). ${ }^{51}$ This royal saint, who succeeded in remaining chaste through two marriages, represents for Bede the ideal of virginity. For Bede, the events of Æhelthryth’s life-including her marriages-- are less important than those surrounding her death and the subsequent translation of her body by her sister, and successor at Ely, Seaxburh. This is because, when Æthelthryth’s tomb is opened her corpse is found to be incorrupt and the tumour on her neck, which was responsible for her death, was miraculously healed. Bede cites this as evidence of her virginal purity. What is so remarkable about Bede’s account of Æthelthryth, however, is that of the three lives of saintly abbesses, this is perhaps the one that most minimizes or overwrites the authority of women. Just as Bede passes quickly over Æthelthryth’s married life, so Bede, while alluding to Æthelthryth’s aunt, Æbbe, abbess of Coldingham (HE 4.20), makes no reference to Æthelthryth’s familial ties to Hild, even though, as Virginia Blanton suggests, 'it is more than reasonable to believe that the women knew one another well and were in some way cognizant of their mutual work as leaders of monastic communities'. ${ }^{52}$ Bede also overlooks important information about Seaxburh. Rosalind C. Love points out that Bede makes no reference to Seaxburh's own

\footnotetext{
${ }^{51}$ Blanton, Signs of devotion, pp.19-63.

${ }^{52}$ Blanton, Signs of devotion, p.23.
} 
foundation at Minster-in-Sheppey, or to her daughter Eormenhild. ${ }^{53}$ Seaxburh’s other daughter, Earcongota, is discussed only in another context at HE 3.8. Seaxburh, who evidently cultivated her sister's cult, was responsible for ordering the exhumation and, with her nuns, she opened the old coffin, washed and reclothed the body and carried it to its new resting place. However it is not Seaxburh but Bishop Wilfrid who is named as a key witness to the preservation of Æthelthryth’s corpse, while the physician Cynefrith, who attended the dying saint, is cited by Bede as his direct source, and his words are taken as ultimate confirmation of the miracle (HE 4.19). ${ }^{54}$ Remarkably, there are no visions of the saint's ascension experienced by the nuns of her monastery in this narrative. Once again, Bede may have had access to a life of the founding saint produced within her own monastery: Blanton suggests that Æthelthryth’s speech in HE 4.19 (pp.396-7) in which she described her illness as punishment for former vanity may be derived from it. ${ }^{55}$ Even so, compared to the accounts of Hild and Æthelburh, Æthelthryth’s life is, it seems, the life that is most heavily overwritten.

Goscelin of Saint-Bertin

\footnotetext{
${ }^{53}$ Goscelin of Saint-Bertin, Hagiography of the female saints of Ely, ed. and trans., Love, p.xiv.

${ }^{54}$ Blanton, Signs of devotion, pp.35-49.

55 Signs of devotion, p.49.
} 
Hollis is surely correct then in her claim that in the HE Bede 'significantly underrepresented' women's participation in literary culture'. ${ }^{56}$ Bede as an overwriter exerts considerable control over the narratives that he refashions, effectively writing out his female sources and authorities. In some respects his treatment of the saintly abbesses in $H E 4$ can be likened to Boniface's decision not to reproduce Hildelith's account of the vision of the monk of Much Wenlock. However, the second example of monastic overwriting of female sanctity discussed in more detail here, this time from the end of our period is rather different. The late-eleventh century saw a revival of monastic women's participation in literary culture, with the Frenchborn hagiographer Goscelin of Saint-Bertin (c.1035-c.1107) playing a key role. Goscelin contributed to the collection of lives of the Anglo-Saxon female saints at Ely which, as is noted above, emphasized familial as well as spiritual connections between the women, creating a spiritual matrilineage. ${ }^{57}$ If the relations between women in this matrilineage are represented as competitive, as Ridyard suggests, Goscelin nevertheless emphasises the extent to which the women also foster holiness in one another. Thus in his Vita Sancte Werbvrge we are told that Wæburh's mother Eormenhild encouraged her young daughter to enter at a very early age the monastic life from which she herself had hitherto been excluded by marriage. ${ }^{58}$ The Ely lives, and Goscelin's work generally, can be seen as part of a larger project of

\footnotetext{
${ }^{56}$ Stephanie Hollis, 'Wilton as a centre of learning' in Hollis et al (eds.) Writing the Wilton women, pp.307.

${ }^{57}$ See also Goscelin’s treatment of female succession in his translatio of Mildrith, discussed by Hollis in 'Minster-in-Thanet', 57.

${ }^{58}$ Goscelin of Saint-Bertin, Hagiography of the female saints of Ely, ed. and trans. Love, pp.34-5.
} 
Norman promotion, even appropriation, of Anglo-Saxon saints. ${ }^{59}$ More significantly, however, from the perspective of women's literary history, Goscelin also produced a number of works for women, including lives and other texts relating to Æthelburh and her successors at Barking for the nuns there in support of the decision made by Abbess Alviva (Ælfgiva) (d.1080), in the face of ecclesiastical opposition, to translate the bodies of her predecessors to a larger shrine. ${ }^{60}$ Included within these texts is a biography of Alviva herself. ${ }^{61}$ Similarly, the legend of Edith (Eadgyth) was written for the house at Wilton 'to provide this cult with archiepiscopal validation'. ${ }^{62}$ Goscelin's Liber confortatorius, mentioned above, was a work of instruction written for Eve (c.1058-1120), a nun educated at Wilton, who left to become an anchoress at Saint-Laurent du Tertre in Angers. ${ }^{63}$ Goscelin as an overwriter was concerned

${ }^{59}$ See S.J. Ridyard, 'Condigna veneratio: post-Conquest attitudes to the saints of the AngloSaxons’, Anglo-Norman studies 9 (1986), 179-206; and David Rollason, Saints and relics in Anglo-Saxon England (Oxford: Basil Blackwell, 1989), pp.220-39, esp. 223.

${ }^{60}$ Goscelin of Saint-Bertin, 'Texts of Jocelyn of Canterbury which relate to the history of Barking Abbey’, ed. Marvin L. Colker, Studia monastica 7 (1965), 383-460; Paul Antony Hayward, 'Translation-narratives in post-Conquest hagiography and English resistance to the Norman Conquest', Anglo-Norman studies 21 (1998), 81-83; and Georges Whalen, 'Patronage engendered: how Goscelin allayed the concerns of nuns' discriminatory publics’ in Women, the book and the godly: selected proceedings of the St Hilda's conference, 1993, ed. Lesley Smith and Jane H.M. Taylor (Cambridge: D.S. Brewer, 1995), vol. I, pp.129-30. ${ }^{61}$ Goscelin, ‘Texts of Jocelyn of Canterbury’, ed. Colker, 437-8.

${ }^{62}$ Hayward, 'Translation-narratives’, 77.

${ }^{63}$ See Whalen, 'Patronage engendered,’ pp.124-9; and Katherine O’Brien O’Keeffe, ‘Edith’s choice' in Latin learning and English lore: studies in Anglo-Saxon literature for Michael 
with updating and preserving traditions of female sanctity and paid more attention than Bede to the memories, words, and, even the literary activities of devout women. Strikingly, Goscelin records, in his vita of Edith of Wilton (c.961-84), daughter of Abbess Wulfthryth (d.c.1000), that a book of devotional material, including chants and collects, written in Edith's own hand, was preserved in Wilton as an object of veneration. ${ }^{64}$ Hollis suggests that a prayer included by Goscelin in his Liber confortatorius may have been composed by Edith, and taken from this same volume, although it is not attributed to her. ${ }^{65}$ Goscelin clearly sees Edith’s learning as evidence of her piety. Throughout, he emphasises the role of Edith’s mother Wulfthryth as Edith’s mentor and teacher: ‘Ita colligitur in ecclesie gremium, in uirginale collegium, in diuinum gymnasium, in scolas uirtutum, in eiusdem et spiritualis et carnalis genitricis sinum' [So she was gathered into the bosom of the church, the college of virgins, the divine training school, the schools of virtue, into the bosom of her who was at

Lapidge, ed. Katherine O’Brien O’Keeffe and Andy Orchard, 2 vols. (Toronto: University of Toronto Press, 2005), vol.II, pp.253-74.

${ }^{64}$ Goscelin of Saint-Bertin, 'La légende de Ste Édith en prose et verse par le moine Goscelin’, ed. A. Wilmart, Analecta Bollandiana 56 (1938), 55-56; Goscelin of Saint-Bertin, ‘Goscelin’s legend of Edith’, trans. Michael Wright and Kathleen Loncar in Hollis et al (eds.), Writing the Wilton women, p.34.

${ }^{65}$ Hollis, 'Wilton as a centre of learning,' p.310 and n.16. See Goscelin of Saint-Bertin, ‘The liber confortatorius of Goscelin of Saint-Bertin’, ed. C.H. Talbot, Studia Anselmiana 37 (1955), 106; Goscelin of Saint-Bertin, ‘Goscelin’s Liber confortatorius’, trans. W.R. Barnes and Rebecca Hayward in Hollis et al (eds.), Writing the Wilton women, p. 194. 
the same time her spiritual and natural mother $].{ }^{66}$ In one version of Edith’s life it is recorded that she read saints' lives intensively and emulated her aunt Edith of Tamworth and grandmother, Ælfgifu of Shaftsbury. ${ }^{67}$ Nevertheless it remains the case that even as Goscelin recognizes the need to preserve the memory of Edith’s prayers and learning, he does not, in her Vita at least, see the need to preserve the contents of her book of devotions.

What is equally remarkable about his lives however, is that unlike Bede, Goscelin embraced his female sources, drawing on the oral testimony of the nuns at Wilton who,

inter reliqua que ipse oculis conspexere, affirmant confidenter cum aliis idoneis testibus ea que ab his uenerabilibus matribus audiere, qui ipsam sanctam uirginem et uidere, et deuotissime sunt obsequute; quarum et parentele et religiose uite non minorem fidem quam libris noscuntur habere

[as well as the things which they saw with their own eyes, declare confidently, with other appropriate evidence, those things which they heard from the venerable senior

${ }^{66}$ Goscelin, ‘La légende de Ste Édith’, ed. Wilmart, 47; ‘Goscelin’s legend of Edith’, trans. Wright and Loncar, pp.30-31.

${ }^{67}$ Goscelin, ‘La légende de Ste Édith’, ed. Wilmart, 53-5; ‘Goscelin’s legend of Edith’, trans. Wright and Loncar, p.35 n.50; Hollis, 'Wilton as a centre of learning', p.310; Stephanie Hollis, ‘Goscelin’s writings and the Wilton women’ in Hollis et al (eds.) Writing the Wilton women, p.239. 
nuns, who both saw the holy virgin herself and devotedly obeyed her; whose high birth and religious lives are recognized as being equal in credibility to books.] ${ }^{68}$

His Translatio includes visionary accounts comparable to those recorded by Bede in HE 4, such as one experienced after the death of Edith's mother Wulfryth, by a grieving nun. ${ }^{69}$ Similarly, in his account of Æthelburh’s posthumous protection of Barking, Goscelin famously cites the recollections of a nun of Barking:

Sanctimonialis eiusdem monasterii editua fide predicanda Iudith cognominata, quae ad huius regis durauit tempora, ab his ducibus quibus gesta sunt se audisse asserebat sequentia miracula, quorum proximae adhuc supersunt testes in hac ipsa eclesia.

[The nun named Judith, who was sacristan of this monastery and whose faith was eloquent, who lived into the times of this present king, claims to have heard of the

${ }^{68}$ Goscelin, ‘La légende de Ste Édith’, ed. Wilmart, 37; ‘Goscelin’s legend of Edith’, trans. Wright and Loncar, p.24.

${ }^{69}$ Goscelin, 'La légende de Ste Édith’, ed. Wilmart, 275-6;‘Translatio of Edith’ in ‘Goscelin’s legend of Edith’, trans. Wright and Loncar, pp.75-6; Stephanie Hollis, ‘Strategies of emplacement and displacement: St. Edith and the Wilton community in Goscelin's legend of Edith and Liber confortatorius' in A place to believe in: locating medieval landscapes, ed. Clare A. Lees and Gillian R. Overing (University Park, Pennsylvania: The Pennsylvania State University Press, 2006), pp.155-9. 
following miracles from the ealdormen by whom they were performed, and the closest witnesses survive to this day in this very church. $]^{70}$

Judith is no mere witness, however, but an active participant in events. Subsequently, in his description of the translation of Abbess Wulfhilda (d.c.1000), who had refounded Barking in around 970, Goscelin records that Wulfhilda appeared to an anonymous nun in a vision, instructing her that when the tomb was opened, the nun should cover her body with her habit. Judith, on hearing the vision, begged to be allowed to carry out Wulfhilda's request, and when the tomb was opened 'Quam sola Iudith fidelissima ausa contingere cognouit solidum corpus mira integritate' [Judith, the most devout, alone dared to touch her and knew that the

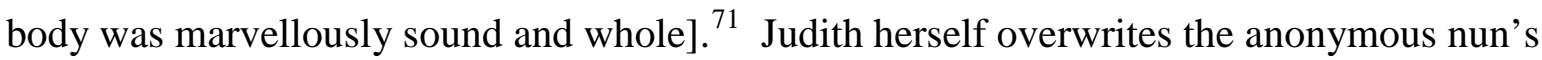
vision by claiming for herself the performance of the dead saint's request.

How should we understand the significantly (?) different attitudes to women as writers, educators and authorities in Bede and Goscelin? It is certainly not the case that women's engagement with literary culture steadily increased. Even following the ninth century Viking attacks and the tenth-century Benedictine reform, Hollis argues that the hiatus in women's

${ }^{70}$ Goscelin, 'Texts of Jocelyn of Canterbury’, trans. Colker, 412; Goscelin of Saint-Bertin, 'Goscelin of St Bertin: lives of the abbesses at Barking', trans. Vera Morton in Guidance for women in twelfth-century convents, trans. Vera Morton, with an interpretative essay by Jocelyn Wogan-Browne (Cambridge: D.S. Brewer, 2003), p.146.

${ }^{71}$ Goscelin, 'Texts of Jocelyn of Canterbury’, trans. Colker, 432; 'Lives of the abbesses at Barking,' trans. Morton, p.149. 
engagement in literary culture continued from the tenth century until after the Norman invasion. She contends that, Goscelin aside, in contrast to the situation before the tenthcentury, 'there are no known Latin works written either for or by monastic women in the late Anglo-Saxon period as it is usually defined' (Hollis's emphasis). ${ }^{72}$ Stricter rules of enclosure must have restricted the access religious women had to wider textual and scholarly communities, and thus limited their engagement with literary culture. Against this, the Passio Sancti Eadwardi or Passion of St Edward (a work influenced by Goscelin) was, as Paul Antony Hayward points out, quite possibly written by a nun of Shaftsbury for her convent in the late eleventh-century. ${ }^{73}$ Furthermore, there is, as Hollis notes, evidence of works at this time being produced for non-monastic women. There is also evidence of female book ownership especially, although not exclusively, amongst aristocratic and royal women, in the centuries immediately before and after the conquest, ${ }^{74}$ and, in addition to the works produced for the pre-Conquest queens Emma and Edith, Matilda (1080-1118), wife of Henry I, commissioned a life of her mother St Margaret of Scotland (d.1093). ${ }^{75}$ It is important to locate Goscelin’s hagiographies within this wider context of female patronage and engagement with literary culture: as we have seen, he too was commissioned to write for and by women, and thus he produced works updating pre-existing narratives of female sanctity,

\footnotetext{
${ }^{72}$ Hollis et al (eds.) Writing the Wilton women, p.7; and see Hollis, 'Wilton as a centre of learning,’ pp.307-8.

${ }^{73}$ Edward king and martyr, ed. Christine E. Fell, Leeds Texts and Monographs, new series 3 (Leeds: University of Leeds, 1971); Hayward, ‘Translation-narratives’, 85.

${ }^{74}$ Hollis, 'Wilton as a centre of learning', pp.308-9.

${ }^{75}$ Lois L. Huneycutt, 'The idea of the perfect princess: the Life of St Margaret in the reign of Matilda II (1100-1118)’ in Anglo-Norman studies 12 (1989), 81-97.
} 
and tailored them for his female monastic audience. Whereas Bede was not answerable to the nuns at Whitby, Barking and Ely, Goscelin’s histories of Barking and Wilton were designed to meet the needs of the sisters in those houses. While it is interesting to speculate as to why the nuns at Barking and Wilton did not produce their own histories—was it simply the case that the employment of a renowned hagiographer seemed more appropriate to women of their high social standing? - Goscelin’s lives nevertheless provide evidence of that these women were both learned and literary. Furthermore, the existence of a text like the Shaftesbury Passio Sancti Eadwardi, may even indicate that Goscelin's works introduced a new phase in early medieval women's writing and engagement with literary culture in England that would reach its apex in the French women-authored hagiographies of the twelfth and thirteenthcenturies.

In touch with the past: Christina of Markyate

The example of Christina of Markyate illustrates very clearly the complexity of women's engagements with literary culture at the end of the early medieval period, while at the same time it somewhat problematizes the picture of women's literary and spiritual history that has emerged so far, dominated successively as it is by powerful abbesses and queens. Christina (formerly Theodora) of Markyate was born some thirty years after the Conquest. Her father, Autti, was a wealthy Anglo-Saxon, who at one point presided over the Gild Merchants of Huntingdon. Her mother, Beatrix, judging from her name, may have been French. From her 
earliest years, Christina had a strong attachment to St Albans Abbey. As a young child, Christina determined to dedicate herself to God, but this decision was met with fierce opposition from her parents, and was persuaded, very much against her will, to marry. Christina fled from her family and into hiding, living for many years as a recluse. Eventually she was released from her marriage, and, having gained the patronage of Geoffrey, abbot of St Albans, she took her vows in c.1131. Having gathered a community of followers around her, she became founding prioress of Markyate in 1145. Christina does not offer an élite model of female sanctity in the way that Hild, Æthelthryth, or Æthelburh, or their successors do; nor indeed was she canonized, although she was evidently revered as a holy woman by her supporters and followers. Nevertheless, she was certainly privileged. Hollis and WoganBrowne suggest that 'had Christina not been perceived as pre-eminently marriageable', her parents might have 'even set up a small foundation for her, of which she might expect to become the prioress'. ${ }^{76}$ As it was, Christina lived for many years outside the convent, initially with the female recluse Alfwen, then with the revered hermit, Roger of St Albans (d.c.1122), and subsequently with a small group of women. As Sarah Foot has argued, this form of nonmonastic female piety is particularly characteristic of the late Anglo-Saxon church, and a devout woman such as Christina would have been described as a nunne rather than a mynecenu [cloistered woman]. ${ }^{77}$

\footnotetext{
${ }^{76}$ Stephanie Hollis and Jocelyn Wogan-Browne, ‘St Albans and women’s monasticism: lives and their foundations in Christina's world' in Christina of Markyate: a twelfth-century holy woman, ed. Samuel Fanous and Henrietta Leyser (London: Routledge, 2005), pp.35-6.

${ }^{77}$ Sarah Foot, Veiled women i: the disappearance of nuns from Anglo-Saxon England (Aldershot: Ashgate, 2000), pp.104-10.
} 
Christina's first language was English, as we are reminded by the incomplete Life of Christina of Markyate, written by an anonymous monk of St Albans, which records that her spiritual guide Roger addressed her as ““myn sunendaege dohter”’ ['my Sunday daughter’]. ${ }^{78}$ Following her profession, Christina may well have begun a programme of education to improve her literacy, ${ }^{79}$ but as Hollis and Wogan-Browne point out 'Christina’s world must have already been aurally trilingual even before she acquired a reading knowledge of written French or Latin' ${ }^{80}$ Certainly, long before her profession, Christina’s devotional practices centred on reading and reciting or singing the Psalms (Life, pp.92-3 and 98-99). It is not clear whether she could also write. However, Christina's own chosen forms of cultural expression were weaving, sewing and embroidery (see, for example, Life, pp.160-3). This is not unusual amongst pious women. Goscelin's Vita of Edith, for example, records her skills in embroidery. ${ }^{81}$ Furthermore needlework would have been a form of artistry that was not restricted to the aristocracy. However, what sets Christina apart from other holy women of the late Middle Ages is that she is, famously, associated with two important books that have survived to the present day: the beautifully illustrated St Albans Psalter, which was produced

\footnotetext{
${ }^{78}$ The life of Christina of Markyate: a twelfth century recluse, ed. and trans. C.H. Talbot, revised ed. (Toronto: University of Toronto Press and the Medieval Academy of America, 1998), pp.106-7. All in-text references are to this edition.

${ }^{79}$ Watt, Medieval women's writing, p.22; for a more detailed discussion of Christina's engagement with literary culture and cultural production, see Watt, Medieval women's writing, pp.19-38.

80 'St Albans and women’s monasticism’, p.26.

${ }^{81}$ Goscelin, 'La légende de Ste Édith’, ed. Wilmart, 69 and 79; 'Goscelin’s legend of Edith’, trans. Wright and Loncar, pp. 38 and 48.
} 
or adapted for Christina and her fellow nuns, ${ }^{82}$ and the unfinished Life of Christina of Markyate (a copy of which was at one time in the possession of Markyate Priory). While both these books seem to have been commissioned by Geoffrey of St Albans, it is noteworthy that Christina’s sister Margaret, who joined the growing community of recluses around Christina at Markyate, and subsequently entered the Priory, may have contributed to them. Certainly she is recorded as having believed that Christina's visions ought to be remembered in posterity (Life, pp. 154-5) and she may well have provided information to Christina’s biographer. Furthermore, Margaret seems to have been responsible for adding family obits to the calendar of the St Albans Psalter, including Christina’s own obit. Christina's contribution to the Psalter may have been fabric curtains, which at one stage were sewn into the manuscript to protect some of the illustrations.

The textual traces of Christina's life provide a wealth of evidence that she modelled herself on Anglo-Saxon models of piety, and on women saints in particular. ${ }^{83}$ The names of three Anglo-Saxon women saints appear in the calendar of the St Albans Psalter: Hild, Æthelthryth of Ely, and Frithuswith (Frideswide), founding abbess of Oxford (d.727). Many aspects of the Psalter reveal that it was tailored specifically for Christina and her nuns: for

\footnotetext{
$82<$ http://www.abdn.ac.uk/stalbanspsalter>

${ }^{83}$ Hollis and Wogan-Browne, 'St Albans and women’s monasticism'; Shari Horner, The discourse of enclosure: representing women in Old English literature (Albany, NY: SUNY Press, 2001), pp.173-85.
} 
example great emphasis is place in the illustrations on the roles of women. ${ }^{84}$ The AngloSaxon saints in the calendar seem to have been quite deliberately chosen as early founding abbesses and mothers of the English church. Æthelthryth of Ely, as we have seen, was twice married before she became a nun, and Frithuswith of Oxford withstood pressure to marry in order to fulfil her vow to Christ, and also had to escape her suitor and live as a hermit. Within The Life of Christina of Markyate, specific parallels are drawn with the example of another, in this case Roman, female saint. In a highly charged scene, Christina tried to persuade her husband Burthred to agree to a chaste marriage by telling him about the exemplary partnership of St Cecilia and her husband Valerian (Life, pp.50-51). It is interesting to speculate about how Christina might have encountered these, and other, saints’ histories. She would have been familiar with hagiographies written in her mother tongue. The earliest surviving accounts of Frithuswith's legend --including that recorded by William of Malmesbury — are in Latin and date to the early twelfth century, but it is possible that earlier vernacular versions existed. ${ }^{85}$ As for Hild and Æthelthryth, an old English version of Bede's $H E$ was in circulation in the tenth and eleventh centuries. ${ }^{86}$ Furthermore, the vernacular lives of Æthelthryth and Cecilia were amongst those written by Ælfric of Eynesham (c.950-c.1010), which were still in circulation in Christina’s life-time. Ælfric did not claim to write the lives specifically for women (they are dedicated to two noble male

\footnotetext{
${ }^{84}$ Jane Geddes, 'The St Albans Psalter: the abbot and the anchoress' in Christina of Markyate, ed. Fanous and Leyser, pp.204-5.

${ }^{85}$ John Blair, 'Saint Frideswide reconsidered', Oxoniensia 52 (1987), 71-127.

${ }^{86}$ The Old English version of Bede's ecclesiastical history of the English people, ed. and trans. Thomas Miller, Early English Text Society 95, 96 and110, 111 (London: N. Trübner, 1890 and 1898), parts i and ii.
} 
patrons, the father and son Æthelweard and Æthelmær), but he clearly envisaged it being read by devout individuals like Christina. ${ }^{87}$

However, there is also reason to think that Christina might have encountered some of her models of sanctity through the post-Conquest overwritings of the insular saints' lives. Significantly, Christina’s patron, Geoffrey of St Albans, was an associate of Osbert of Clare. ${ }^{88}$ Osbert of Clare was English born, but probably of Norman-French parentage. In his letter to Adelidis of Barking, written when he was Prior of Westminster, he summarizes events from the life of Æthelthryth, ${ }^{89}$ and also discusses in detail Æthelburh of Barking’s ascension to heaven. ${ }^{90}$ In his conclusion to the latter account, he directs the interested reader to read Bede’s Historia Ecclesiastica for herself. ${ }^{91}$ Osbert also cited St Cecilia as an ideal of virginity, praising her achievements thus:

${ }^{87}$ Ælfric’s lives of saints, ed. Walter W. Skeat, Early English Text Society 76 and 82 (London: N. Trübner, 1881), vol. I, pp.1-2.

${ }^{88}$ Hollis and Wogan-Browne, 'St Albans and women’s monasticism’, p.42.

${ }^{89}$ Osbert of Clare, The letters of Osbert of Clare, prior of Westminster, ed. E.W. Williamson, (London: Oxford University Press, 1929), pp.156-7; Osbert of Clare, 'Osbert of Clare, prior of Westminster, to Adelidis, abbess of Barking', trans. Vera Morton in Guidance for women, trans. Morton, pp.24-6.

${ }^{90}$ Osbert of Clare, Letters, ed. Williamson, pp. 175-7; 'Osbert of Clare, prior of Westminster, to Adelidis, abbess of Barking', trans. Morton, pp.46-8.

${ }^{91}$ Osbert of Clare, Letters, ed. Williamson, p.177; 'Osbert of Clare, prior of Westminster, to Adelidis, abbess of Barking', trans. Morton, p.48. 
haec sunt praedicanda insigniter illius admirabilis feminae opera, quae femineam mentem non aspirant, sed virilem constantiam in illius redolent libertate.

[These are the outstanding works of evangelising by this wonderful woman; they do not express a woman's mind but in the privileged position of her burial reflect masculine firmness]. ${ }^{92}$

In her Life, Christina is, on a number of occasions, described as transcending her sex, notably on the occasion of her flight from her family, when she is reported to have encouraged herself with the words “"Quid sexum feminei vereris? Virilem animum indue...”" ["Why do you respect your feminine sex? Put on manly courage...”] (Life, pp.92-3). Texts such as Goscelin's Vita of Edith also resonate with Christina's Life. Hollis and Wogan-Browne, point out, for example, that Goscelin's representation of the spiritual friendship of Edith and Bishop Dunstan, which is likened to that between the Virgin Mary and John the Apostle, is mirrored in Christina's vision of the Crucifixion, in which Christina is Mary and Geoffrey of St Albans is John. ${ }^{93}$ Both narratives also open with natal visions. At the time of Edith's birth, Goscelin recounts that a ray of light shone from the baby's head as she cried out for the first time. ${ }^{94}$ Edith's mother Wulfthryth recognized the significance of what had happened and thereafter left her husband to join the monastery. Christina’s own mother, Beatrix, experienced a miracle, in this case during her pregnancy, in which a white dove flew to her from the church and remained in her presence for seven days (Life, pp.34-5). However, while

\footnotetext{
${ }^{92}$ Osbert of Clare, Letters, ed. Williamson, p.156; 'Osbert of Clare, prior of Westminster, to Adelidis, abbess of Barking', trans. Morton, p.24.

93 'St Albans and women’s monasticism', pp.33-4.

${ }^{94}$ Goscelin, 'La légende de Ste Édith’, ed. Wilmart, 42; ‘Goscelin’s legend of Edith’, trans. Wright and Loncar, p.27; see O’Brien O’Keeffe, ‘Edith’s choice’, pp. 256-7.
} 
the Life reveals Beatrix realized the significance of what had occurred (and indeed she is named as the writer's authority), the subsequent narrative illustrates that she strongly and indeed violently resisted her daughter’s spiritual path. Nevertheless, Christina’s decision as a young child to dedicate herself to God resonates with Edith's self-consecration aged only two. ${ }^{95}$ Although these examples may indicate shared traditions of Anglo-Saxon sanctity rather than direct influence, it is never the less the case that such narratives must have been in wide circulation, whether in English or Latin. Yet whereas the overwritings of the lives of Anglo-Saxon saints by Goscelin and others can be seen as Norman appropriations, Christina's emulation of such models may be seen as Anglo-Saxon resistance. ${ }^{96}$ Nevertheless, at least following her profession if not before, Christina also encountered noninsular models of piety recorded in languages that were not her mother tongue. That Christina identified with, or was encouraged by Geoffrey of St Albans, to identify with, alternative French traditions of sanctity is most forcefully indicated by the inclusion within the St Albans Psalter of the Chanson d'Alexis, which focuses on a man who fled marriage to live an ascetic and eremitic life, and also on the bride with whom Alexis is eventually reconciled in heaven. ${ }^{97}$ Beyond those texts directly referred to or included in her books (the lives of St Cecilia and Alexis), it is impossible to know whether Christina had read the work of Bede, Ælfric, Osbert or Goscelin — the line of proven descent has died out. The influence is

${ }^{95}$ Goscelin, ‘La légende de Ste Édith’, ed. Wilmart, 44; ‘Goscelin’s legend of Edith’, trans. Wright and Loncar, p.29; see O’Brien O’Keeffe, ‘Edith’s choice’.

${ }^{96}$ See Hayward, 'Translation-narratives'.

${ }^{97}$ See Emma Campbell, 'Clerks and laity’ in The Cambridge companion to medieval French literature, ed. Simon Gaunt and Sarah Kay, (Cambridge: Cambridge University Press, 2008), pp.219-23. 
earlier saints should not be understood in genealogical terms but as a touch across time. Furthermore, Christina is not simply a Cecilia or an Alexis, a Hild, an Aethelthryth, a Frithuswith, or an Edith. It is clear that with the help of her spiritual advisors, her followers, her supporters, and her biographer she too overwrites--adapts and revises--these models of female sanctity.

\section{Conclusion}

The historiography of female sanctity establishes strong connections between the early Anglo-Saxon period and the later Middle Ages, but it is not a continuous history. While pieces or traces remain of Anglo-Saxon women's writing, much has been destroyed or has been heavily overwritten. That women's literary history in the early medieval period, especially the literary history associated with the female monasteries, does not follow a straightforward trajectory as is indicated by the hiatus in works associated with women from the ninth-century until after the Conquest. Nevertheless, that the women's houses at Wilton and Barking were still, by the late Anglo-Saxon period, centres of literary culture is indicated in the writings of Goscelin and Osbert of Clare, although, as the example of Christina of Markyate illustrates so vividly, women's engagement with literary culture was not limited to such centres. Yet, aside from anonymous texts such as Passio Sancti Eadwardi, or the lost work of Muriel of Wilton, it is not until the second half of the twelfth-century that we find more extensive evidence of women's participation in literary culture that extended far beyond patronage and reading. The late twelfth century introduced a new phase in women's literary history: we might even think of this as the Barking renaissance, because of the central role 
played by the abbey. In addition to the works of Marie de France (who may have been a royal abbess, according to some critical opinion), three Anglo-Norman saint's lives have survived from this period which are known to be authored by women: a life of Edward the Confessor, by an anonymous nun of Barking (the so-called 'nun of Barking'); the Life of St Catherine by Clemence of Barking (fl. 1166-c.1200); and the life of St Audrey (Æthelthryth) written by another Marie, possibly of Chatteris Abbey in Cambridgeshire. ${ }^{98}$ All three writers bring their own creativity to bear on their translations, and in each life, there is a strong sense of a female voice, whether that be through their female subjects in the case of the lives of Audrey and Catherine, or — in the case of the life of Edward—-through Queen Edith, the wife of the saintly subject. Here overwriting is a useful metaphor for translation, as it indicates some of the originality inherent in updating a work for a new audience, or a new purpose. Indeed, Clemence of Barking explicitly reflects upon the inadequacy of her source:

Ele fud jadis translaté

Sulunc le tens bien ordené;

Mais ne furent dunc si veisdus

Les humes, ne si envius

Cum il sunt al tens ki est ore

E aprés nus serrunt uncore.

Pur ço que li tens est mué

\footnotetext{
98 Jocelyn Wogan-Browne, ““Clerc u lai, muÏne u dame”: women and Anglo-Norman hagiography in the twelfth and thirteenth centuries' in Women and literature in Britain 11501500, ed. Carol M. Meale, reprinted with additional material (Cambridge: Cambridge University Press, 1996), pp.61-85; Wogan-Browne, Saint’s lives, pp. 207-12, 227-45, and 249-56.
} 
E des humes la qualité

Est la rime vil tenue

Car ele est asquans corrumpue.

Pur ço si l'estuet amender

E le tens selunc la gent user.

[It was translated before and well set out according to the standards of the time. But people then were not so hard to please or so critical as they are in our day, and will be even more so after we are gone. Because times and men's quality have changed, the poem is held in low esteem, for it is somewhat defective in places. So it is necessary to correct it and make the times conform to the people]. ${ }^{99}$

While the nuns of Barking may have outsourced the rewriting of their own history in the previous century, the pressure to update and refashion the narrative of this legendary woman, who evidently gave so many nuns and laywomen a model of learned piety, provided sufficient impetus for Clemence to rewrite the story for her sisters and other religious women. The Life of St Catherine-rewritten to 'make the times conform to the people'-- thus offers an appropriate end point for this study of female sanctity and the relics women's writing in the early Middle Ages.

\footnotetext{
${ }^{99}$ The life of St Catherine, ed. William MacBain, Anglo-Norman Text Society 18 (Oxford: Blackwell, 1964), ll.35-46; 'The life of St Catherine' in Virgin lives and holy deaths: two exemplary biographies for Anglo-Norman women, trans. Jocelyn Wogan-Browne and Glyn S. Burgess (London: Everyman, 1996), p.3.
} 